\title{
Analisis Abrasi Pantai Pada Akses Jalan Bahumbelu - Morowali Sulawesi Tengah
}

\author{
Asep Irwan ${ }^{1}$ \\ Teknik Sipil, Fakultas Teknik dan Desain, Institut Teknologi Sains Bandung, Bekasi, Indonesia \\ Email: asep.irwan@itsb.ac.id
}

Informasi naskah:

Diterima:

24 Mei 2019

Direvisi:

04 Agustus 2019

Disetujui terbit:

06 Agustus 2019

Diterbitkan:

07 Agustus 2019

\begin{abstract}
Abstrak
Abrasi pantai yang terjadi pada akses jalan Bahumbelu menuju Morowali Sulawesi Tengah saat ini kondisinya sudah mengkwatirkan, lokasi yang berhadapan langsung dengan laut terbuka dan sering terjadi hantaman gelombang laut sehingga dapat mengakibatkan bibir pantai semakin mundur dan masuk ke daratan. Meskipun saat ini dibeberapa titik sudah terpasang oleh tembok laut atau sea wall namun erosi dibeberapa tempat sudah terjadi dan mengakibatkan jalan amblas terutama yang belum diapasang seawall. Tujuan dari penelitian ini adalah melakukan analisis abrasi pantai dengan bantuan program GENESIS, program ini digunakan untuk memprediksikan garis pantai dalam jangka panjang sebagai reaksi terhadap kondisi gelombang pada struktur bangunan pelindung pantai. Prediksi ini dimaksudkan untuk mengetahui perubahan garis pantai yang terjadi dalam kurun waktu tertentu berdasarkan kondisi eksisting sehingga dapat diketahui perubahan garis pantai yang terjadi. Data yang digunakan dalam penelitian ini adalah data hasil pengukuran lapangan yaitu berupa data kedalaman perairan, garis pantai dan data hasil pengolahan gelombang dari data angin. Berdasarkan hasil simulasi yang dilakukan dengan kala ulang 2 tahun perubahan garis pantai terjadi abrasi sebesar 4 meter dan akresi yang terjadi sebesar 3 meter dengan volume sedimen $-1360 \mathrm{~m}^{3}$. Nilai negatif pada volume sedimen tersebut menunjukkan terjadinya erosi. Pada area sekitar bangunan pelindung pantai eksisting terjadi perubahan garis pantai sebesar 3,5 meter akresi dan 4 meter abrasi. Selanjutnya hasil simulasi kala ulang 5 tahun dan 10 tahun cenderung meningkat dimana kecenderungan perubahan garis pantai masih mengikuti pola hasil tahun sebelumnya yang artinya pola akresi dan abrasi masih belum pada titik keseimbangan sehingga terjadi perubahan pola perubahan garis pantai baru. Sehingga berdasarkan hasil simulasi GENESIS didapatkan rekomendasi penanganan terhadap ancaman abrasi pada lokasi studi yaitu dengan memperbaiki tembok laut eksisting dan menambahkan struktur pelindung pantai yang dibuat sejajar pantai yaitu Revetment.
\end{abstract}

Kata-kunci: abrasi, seawall, genesis, revetment 


\section{PENDAHULUAN}

Permasalahan abrasi pantai di beberapa wilayah di Indonesia menjadi salah satu fenomena alam yang secara alami terjadi. Fenomena abrasi ini menggambarkan pengikisan daerah pantai yang terjadi karena pengaruh gelombang dan arus laut destruktif. Pengikisan yang dapat menyebabkan berkurangnya daerah pantai ini menjadi sasaran pertama terjadinya abrasi. Jika dibiarkan, abrasi akan terus menggerogoti bagian pantai sehingga garis pantai akan semakin menyempit dan apabila tidak diatasi lama kelamaan daerahdaerah yang permukaannya rendah akan tenggelam. Dalam kaitan ini pemadatan daratan mengakibatkan permukaan tanah turun dan tergenang air laut sehingga garis pantai berubah. Pantai dikatakan mengalami abrasi bila angkutan sedimen yang terjadi ke suatu titik lebih besar bila dibandingkan dengan jumlah sedimen yang terangkut ke luar dari titik tersebut $^{[1]}$. Salah satu daerah yang menjadi kajian dalam penelitian ini adalah terletak pada akses jalan Bahumbelu Kabupaten Morowali Provinsi Sulawesi Tengah di mana daerah ini berdasarkan hasil pengamatan lapangan sudah mengalami pengikisan pantai terutama pada jalan yang tidak dilindungi oleh bangunan penahan abrasi pantai.

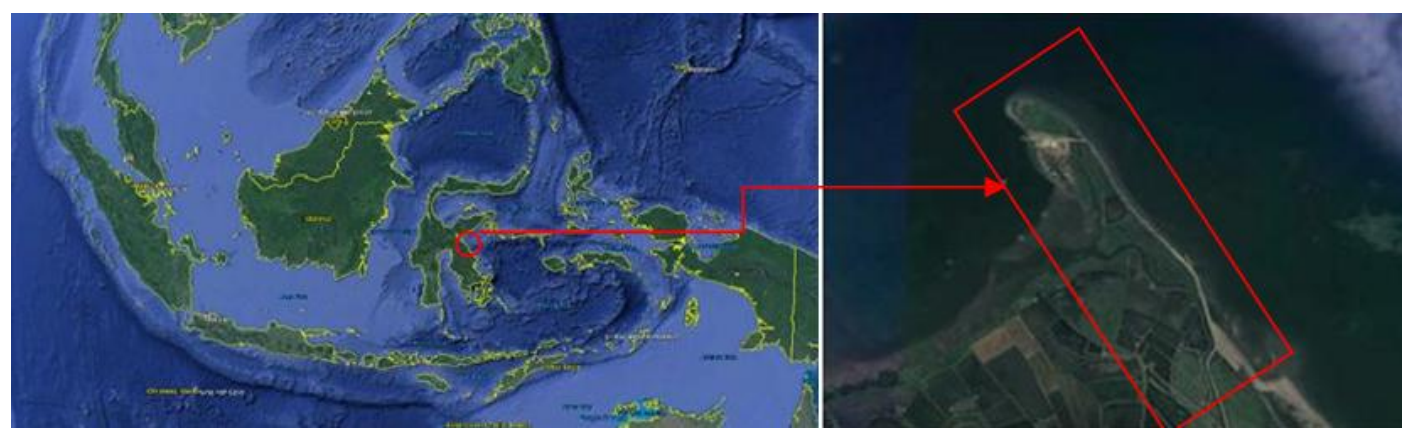

Gambar 1. Lokasi area studi

Wilayah studi terletak pada koordinat $02^{\circ} 10^{\prime} 43.67^{\prime \prime} \mathrm{LS}$ dan $121^{\circ} 40^{\prime} 55.28^{\prime \prime} \mathrm{BT}$, dimana salah satu permasalahan yang sangat penting yang perlu ditanggulangi secara cepat adalah masalah abrasi pantai. Sebelum dilakukan penanganan secara serius maka tahap pertama yaitu dilakukan kajian mengenai seberapa besar perubahan garis pantai yang terjadi di lokasi kajian. Kondisi eksisting saat ini menunjukkan sudah terdapat bangunan penahan abrasi yaitu seawall atau tembok laut namun di beberapa daerah lainnya masih belum dipasang tembok laut sehingga pada daerah inilah yang mengalami perubahan garis pantai secara terus menerus. Perubahan ini terjadi karena material yang dibawa oleh arus mengakibatkan perpindahan material dari satu lokasi ke lokasi lain. Jika gelombang ekstrem terjadi, maka material yang melayang tidak akan kembali ke posisi semula, sehingga satu sisi akan kehilangan material (erosi) di sisi lain akan mendapatkan material tambahan (sedimentasi). 


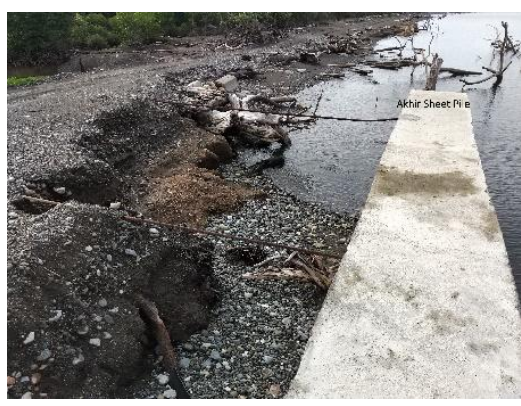

(a)

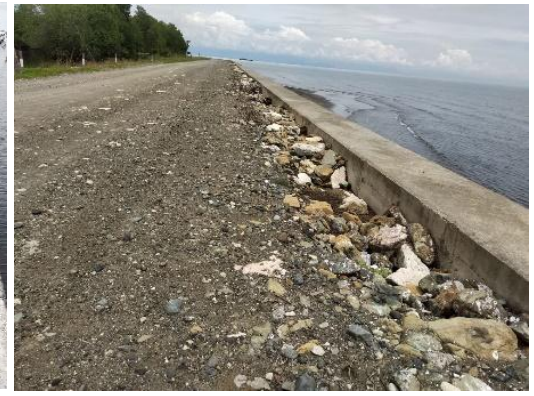

(b)

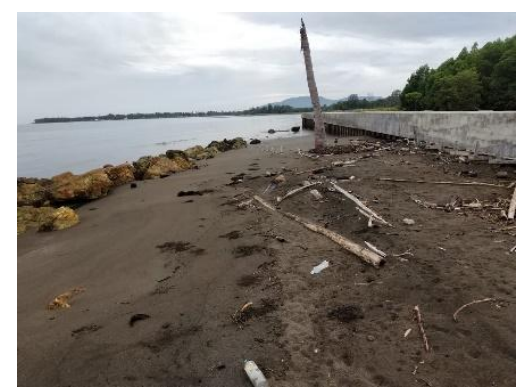

(c)

Gambar 2. (a) Kondisi erosi pada titik akhir seawall; (b) Kondisi jalan yang rusak; (c)

Sedimentasi (Sumber : Pengamatan Lapangan, 2018)

Berdasarkan pada kajian tersebut penelitian ini akan memfokuskan pada simulasi perubahan garis pantai dengan menggunakan program GENESIS sebagai bantuan untuk memprediksikan perubahan garis pantai dengan kala ulang 2 tahun, 5 tahun dan 10 tahun.

\subsection{Dasar Pemodelan GENESIS}

Untuk mensimulasikan permasalahan yang terjadi di lokasi studi, digunakan perangkat lunak GENESIS. Perangkat lunak GENESIS digunakan untuk memperlihatkan besar transport sedimen sejajar pantai dan perubahan garis pantai di lokasi kajian. Batasan yang digunakan dalam pemodelan adalah sebagai berikut:

1. Panjang garis pantai yang disimulasi $1.5 \mathrm{~km}$ dengan jarak antar grid $20 \mathrm{~m}$.

2. Periode simulasi 2 tahun, 5 tahun dan 10 tahun.

3. Data Gelombang 1 tahun

4. Efek pasang surut terhadap perubahan garis pantai tidak diperhitungkan.

GENESIS (Generalized Model for simulating Shoreline) adalah perangkat lunak yang dikembangkan untuk memodelkan perubahan garis pantai dan transpor sedimen sejajar garis pantai yang disebabkan oleh mekanisme gelombang pecah. Asumsi dasar model GENESIS “one line simulation” yaitu ${ }^{[2]}$ :

1. Transpor sedimen hanya terjadi di surf zone

2. Transpor sedimen sejajar pantai terjadi akibat aksi gelombang pecah

3. Detail struktur terinci di seputar pantai dapat diabaikan

4. Evolusi garis pantai menggunakan kecenderungan jangka panjang 
Perubahan garis pantai yang dihitung di dalam GENESIS menggunakan persamaanpersamaan yang didapatkan dari konservasi volume sedimen seperti ditunjukkan pada Persamaan 1.

$$
\frac{\partial y}{\partial t}+\frac{1}{\left(D_{B}+D_{c}\right)}\left(\frac{\partial Q}{\partial x}-q\right)=0
$$

Dimana Q adalah laju transport sedimen sejajar pantai yang dihitung sebagai fungsi tinggi gelombang pecah, sudut datang gelombang pecah, dan beberapa karakteristik gelombang lainnya ${ }^{[3]} ; \mathrm{D}_{\mathrm{B}}$ adalah tinggi berm dan $\mathrm{D}_{\mathrm{C}}$ adalah kedalaman laut. Sumbu-X adalah arah sepanjang garis pantai dari kiri ke kanan (jika pengamat memandang ke arah lepas pantai), sedangkan sumbu-y adalah arah ke daerah lepas pantai. Transport sedimen sejajar pantai dihitung dengan menggunakan persamaan berikut ini, yang merupakan rangkaian persamaan yang terdiri atas suku transport sedimen dan suku difraksi yang direkomendasikan Coastal Engineering Research Centre ${ }^{[4]}$ :

$$
Q=\left(H^{2} C_{g}\right)_{b}\left(a_{1} \sin 2 \theta_{b s}-a_{1} \cos 2 \theta_{b s} \frac{\partial H}{\partial x}\right)_{b}
$$

dengan,

$$
\begin{aligned}
& a_{1}=\frac{K_{1}}{16\left(\left(\frac{\rho_{s}}{\rho_{w}}-1\right)(1-p)(1.416)^{5 / 2}\right)} \\
& a_{2}=\frac{K_{1}}{8\left(\left(\frac{\rho_{s}}{\rho_{w}}-1\right)(1-p) \tan \beta(1.416)^{7 / 2}\right)}
\end{aligned}
$$

Dimana $\mathrm{H}$ adalah tinggi gelombang; $\mathrm{C}_{\mathrm{g}}$ adalah kecepatan penjalaran kelompok gelombang menurut teori gelombang linier; $\mathrm{b}$ adalah indeks yang menunjukkan kondisi gelombang pecah; $\theta$ bs adalah sudut datang gelombang pecah terhadap garis pantai setempat; $\mathrm{K}_{1}, \mathrm{~K}_{2}$ adalah koefisien empirik sebagai parameter kalibrasi ( $\mathrm{K}_{1}$ menunjukkan besaran sedimen transport; $\mathrm{K}_{2}$ merupakan kontrol distribusi sedimen di dalam area perhitungan); $\rho_{\mathrm{s}}$ adalah masa jenis sediment $\left(2.65 .103 \mathrm{~kg} / \mathrm{m}^{3}\right) ; \rho_{\mathrm{w}}$ adalah massa jenis air $\left(1.03 .103 \mathrm{~kg} / \mathrm{m}_{3}\right)$; $\mathrm{p}$ adalah porositas sedimen dasar (0.4); tan $\beta$ adalah kemiringan dasar rerata dari garis pantai menuju laut dalam ${ }^{[3]}$.

\subsection{Dasar Pemodelan Gelombang}

Mengingat tidak tersedianya data gelombang hasil pengukuran lapangan di lokasi studi, maka penelitian ini menggunakan data angin 10 tahun dengan interval per 1 jam untuk membangkitkan gelombang dimana metode tersebut dikenal dengan metode Hindcasting. Hindcasting gelombang adalah teknik peramalan gelombang yang akan datang dengan menggunakan data angin dimasa lampau. Data angin dapat digunakan untuk memperkirakan tinggi dan periode gelombang di laut. Terjadinya gelombang di laut paling dipengaruhi oleh tiupan angin ${ }^{[5]}$. 
Penelitian ini menggunakan data angin dari ECMWF (European Centre for MediumRange Weather Forecasts) pada lokasi Perairan Bahumbelu dengan rentang waktu 10 Tahun mulai dari 2009 hingga 2018. Langkah pertama dalam melakukan analisis dan pemodelan garis pantai adalah melakukan pemodelan transformasi gelombang. Untuk keperluan analisis ini digunakan model STWAVE (STeady-state spectral WAVE). Baik model STWAVE maupun GENESIS keduanya berada dalam satu perangkat lunak CEDAS (Coastal Engineering Design \& Analysis System) yang dikembangkan oleh U.S. Army Corps of Engineers' Engineering Research and Development Center ${ }^{[6]}$. Dalam pemodelan gelombang dibutuhkan beberapa data masukan, seperti data bathimetri, gelombang, angin, dan data spasial lokasi penelitian.

\section{METODOLOGI}

Metode yang digunakan dalam penelitian ini adalah menggunakan 2-D finite diffrence menggambarkan bentuk sederhana persamaan keseimbangan spektrum untuk mensimulasikan daerah pantai dengan waktu tak terbatas penyebaran spektrum energi gelombang. Beberapa data input yang dibutuhkan untuk menjalankan program GENESIS diantaranya adalah data posisi garis pantai, data gelombang, data karakteristik sedimen, dan posisi dan dimensi bangunan pantai.

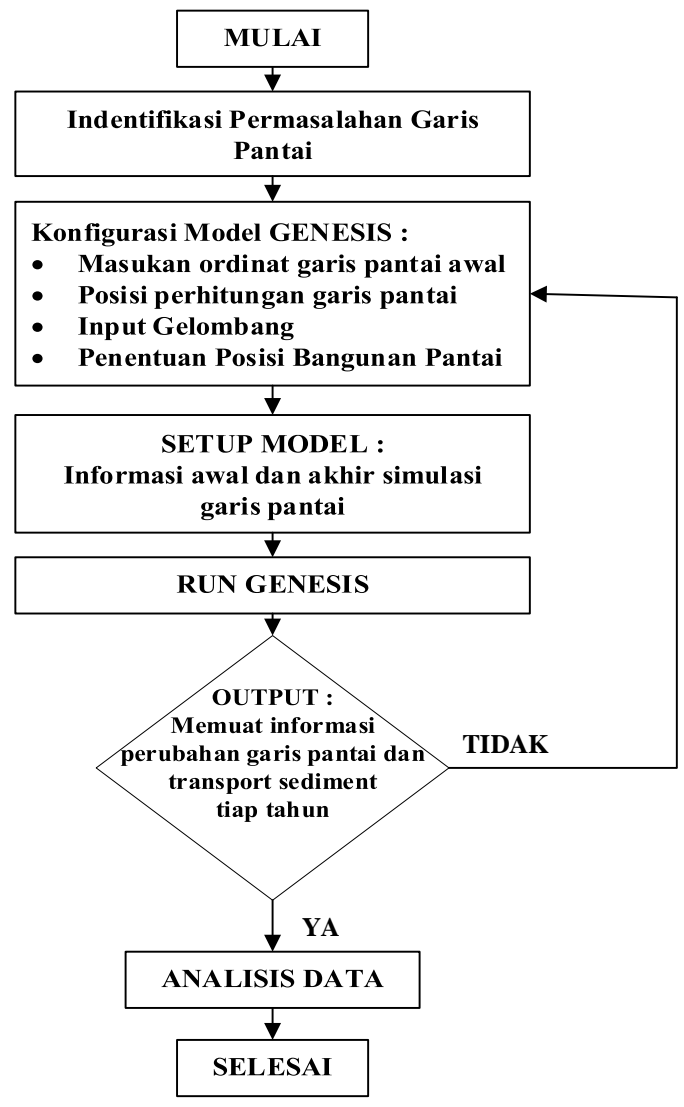

Gambar 3. Diagram Alir Proses Pemodelan GENESIS 
Salah satu langkah penting dalam pemodelan adalah melakukan diskritisasi model dengan membuat mesh (grid model) dengan data bathimetri dan garis pantai yang telah didapatkan. Grid Model ini berdasarkan finite element sederhana di mana batimetri dan garis pantai akan digeneralisasi menjadi batimetri sesuai format kebutuhan perangkat lunak. Grid Simulasi pada lokasi studi dalam program GENESIS yaitu sebagai berikut:

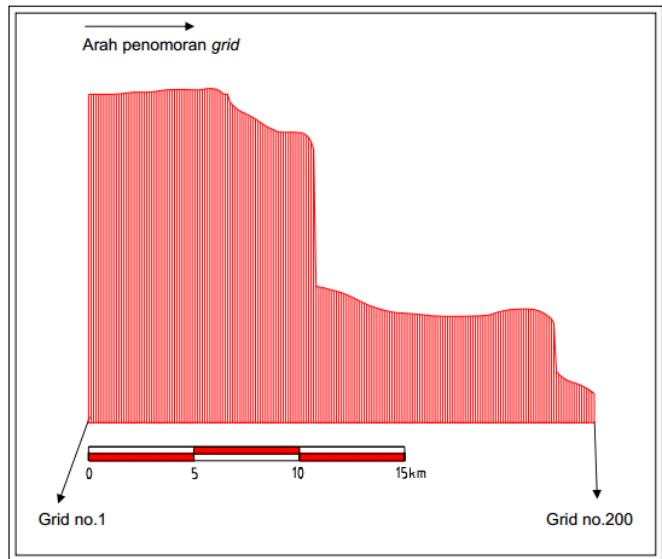

Gambar 4. Grid Pemodelan Pantai Bahumbelu

(Sumber: Hasil Pengolahan Data)

Grid simulasi melingkupi garis pantai serta perairan dimana gelombang akan merambat. Transpor sedimen, posisi struktur, dan batasan garis pantai terletak pada dinding sel, sedangkan titik posisi garis pantai berada di tengah-tengah sel. Grid disepanjang model garis pantai adalah sama, yaitu $\Delta \mathrm{x}=120 \mathrm{~m}$. Semua garis pantai dipindahkan ke dalam sistem koordinat grid ini dengan tidak memperbolehkan dua garis pantai pada satu grid. Struktur eksisting sepanjang garis pantai dalam kasus ini tidak turut diperhitungkan karena faktor dimensi yang tidak terlalu signifikan dibandingkan dengan ukuran garis pantai yang dimodelkan. Hasil proses grid simulasi pada penelitian ini dimulai dari memasukan data batimetri dengan format arah timur, arah utara dan elevasi (xyz) yang kemudian dilakukan pembuatan daerah batas model yang nantinya akan menjadi lokasi pemodelan seperti yang ditunjukan pada gambar di bawah ini.
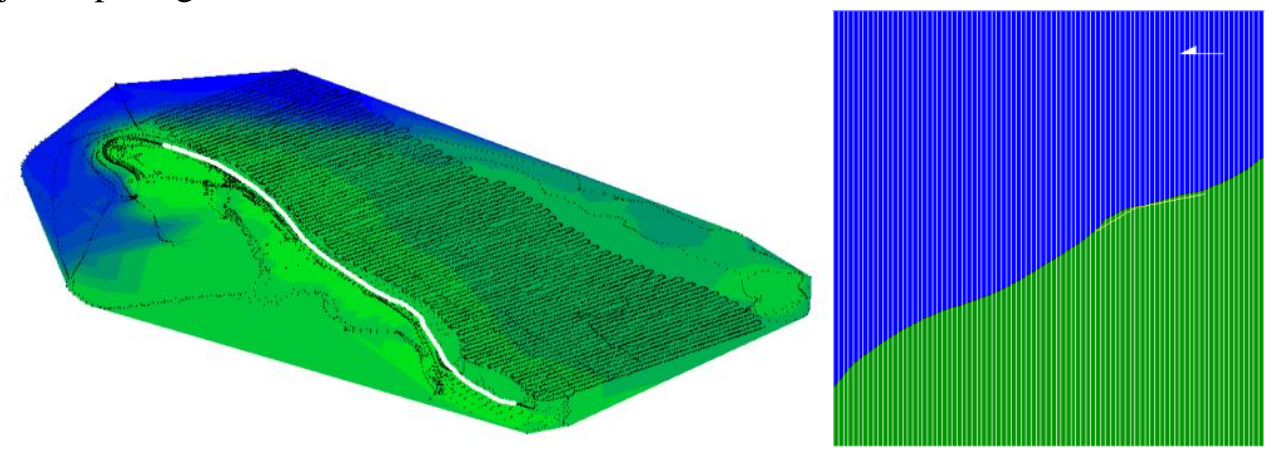

Gambar 5. Grid cell model garis Pantai Bahumbelu

(Sumber: Hasil Pengolahan Data) 


\section{PEMBAHASAN DAN DISKUSI}

Berdasarkan hasil simulasi yang telah dilakukan, prediksi perubahan garis pantai dilakukan guna melihat perubahan garis pantai dalam kurun waktu 2 tahun, 5 tahun dan 10 tahun dengan data gelombang yang di inputkan adalah sebagai berikut:

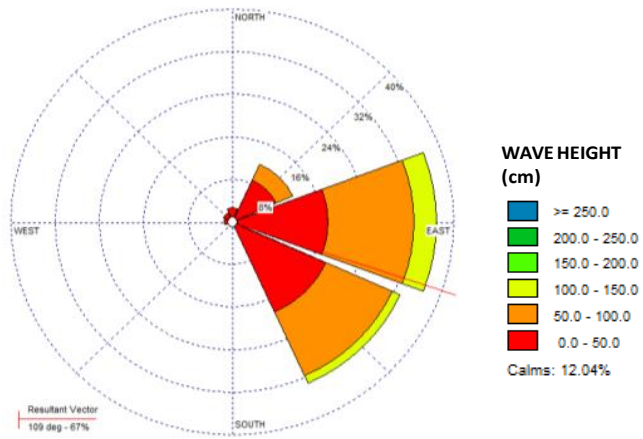

Gambar 6. Data Mawar Angin Perairan Bahumbelu

(Sumber: Hasil Pengolahan Data)

Berdasarkan analisis presentase tinggi gelombang di perairan Bahumbelu, arah dominan gelombang adalah arah Timur dengan prosentase $31,75 \%$ serta tenggara dengan prosentase $22.17 \%$, serta gelombang tenang (calm) $9.74 \%$.

\subsection{Simulasi Model 2 Tahun}

Hasil pemodelan prediksi perubahan garis pantai selama 2 tahun, di mana perubahan garis pantai terjadi abrasi sebesar 4 meter dan akresi yang terjadi sebesar 3 meter dengan volume sedimen $-1360 \mathrm{~m}^{3}$ (tanda negatif menunjukan erosi). Pada area sekitar seawall terjadi perubahan garis pantai sebesar 3,5 meter akresi dan abrasi 4 meter.
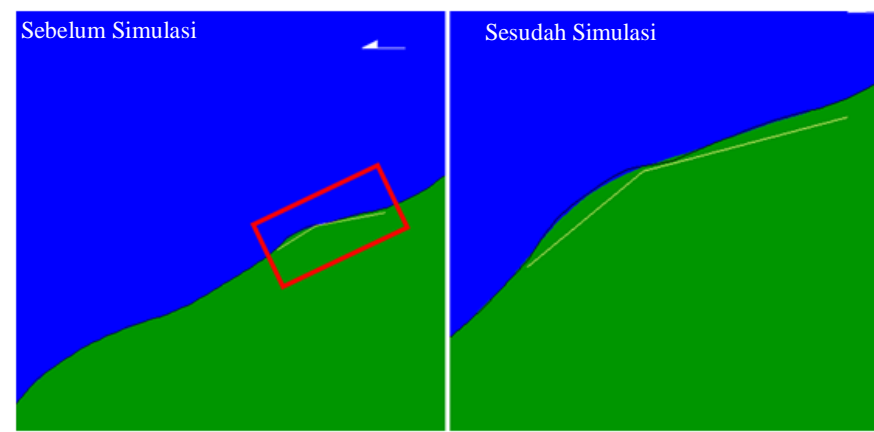

Gambar 7. Perbedaan perubahan garis pantai 2 tahun

\subsection{Simulasi Model 5 Tahun}

Prediksi perubahan garis pantai 5 tahun, di mana kecenderungan perubahan garis pantai mengikuti perunbahan garis pantai 2 tahun, didapatkan abrasi sebesar 4,2 meter naik 0,2 meter dari sebelumnya dan akresi yang terjadi sebesar 4,8 meter dari yang sebelumnya 3 meter dengan volume sedimen $-2470 \mathrm{~m}^{3}$ dan volume erosinya sebesar $1100 \mathrm{~m}^{3}$ meningkat dari sebelumnya $-1360 \mathrm{~m}^{3}$ (tanda negetif menunjukan erosi). Pada area sekitar seawall terjadi perubahan garis pantai sebesar 3,5 meter akresi dan abrasi 4 meter. 


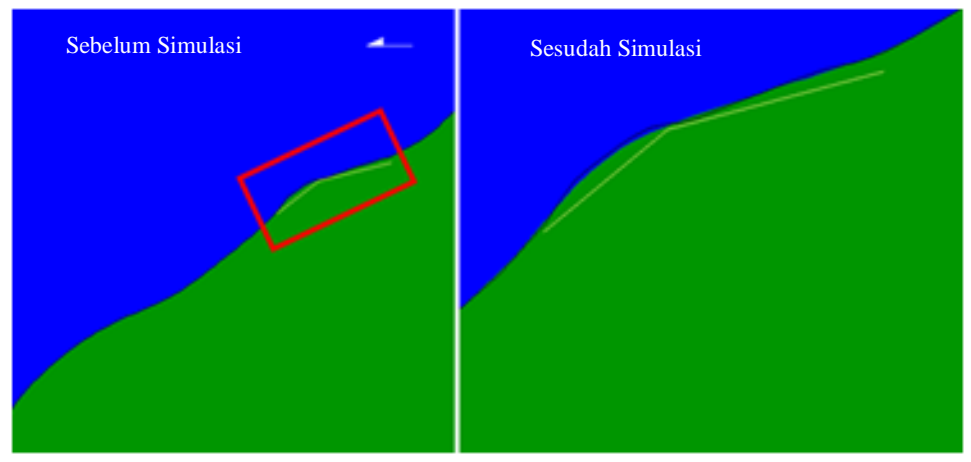

Gambar 8. Perbedaan perubahan garis pantai lima tahun

\subsection{Simulasi Model 10 Tahun}

Prediksi perubahan garis pantai 10 tahun ke depan yang telah dilakukan seperti terlihat pada gambar berikut, di mana hasil perubahan garis pantai maksimal terjadi abrasi 10 meter dan akresi 4 meter dengan volume sedimen transport $-4050 \mathrm{~m}^{3}$.
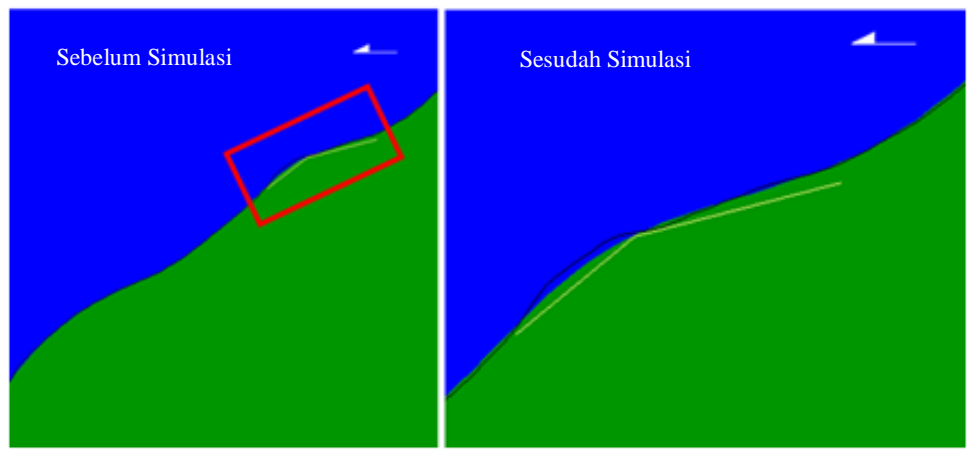

Gambar 9. Perbedaan perubahan garis pantai 10 tahun

Kecenderungan perubahan garis pantai masih mengikuti hasil tahun sebelumnya yang artinya pola akresi dan abrasi masih belum pada titik keseimbangan sehingga terjadi perubahan pola perubahan garis pantai baru. Meskipun perubahan garis pantai masih signifikan yaitu pada prediksi perubahan garis pantai 10 tahun dua kali lipat dari prediksi perubahan garis pantai 2 tahun.

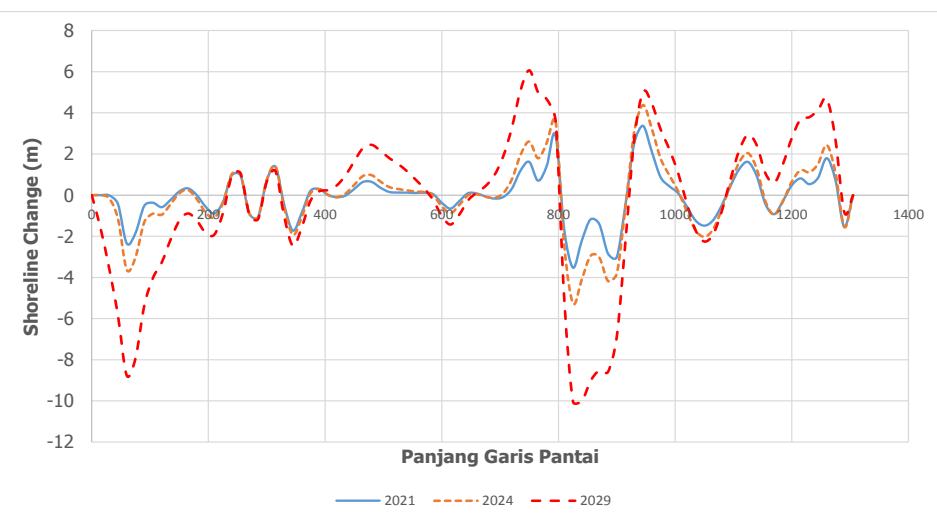

Gambar 10. Perbedaan perubahan garis pantai 2, 5 dan 10 Tahun 


\section{KESIMPULAN}

a. Rata-rata perubahan garis pantai di jalan masuk Bahumbelu Kabupaten Morowali Sulawesi Tengah meningkat setiap kurun waktu 2, 5 dan 10 tahun didapatkan 3,5 meter akresi dan abrasi empat meter pada area seawall eksisting. Hal ini menunjukkan seawall eksisting mengalami beban abrasi yang cukup signifikan, sehingga diperlukan pasangan batu berbentuk talud untuk menahan abrasi tersebut.

b. Profil garis pantai menunjukkan pertambahan dan erosi di berbagai tempat. Pertambahan sedimentasi di sisi utara dan erosi di sisi selatan sama dengan arah gelombang yang dominan dari timur dan tenggara.

c. Dilihat dari rata-rata muatan sedimen, garis pantai Bahumbelu membutuhkan perlindungan pantai yang tepat agar profil garis pantai tidak berubah yaitu dengan memperbaiki tembok laut eksisting dan menambahkan struktur pelindung pantai yang dibuat sejajar pantai yaitu Revetment.

\section{UCAPAN TERIMA KASIH}

Penulis mengucapkan terima kasih kepada semua pihak yang sudah membantu dalam kelancaran penelitian yang dilakukan.

\section{DAFTAR PUSTAKA}

[1] Nur, M. Tajudin. 2004 dan Suwedi, 2006 dalam Damaywanti K, 2013. Dampak Abrasi Pantai terhadap Lingkungan Sosial (Studi Kasus di Desa Bedono, Sayung Demak). Program Pasca Sarjana Universitas Diponegoro.

[2] Fajra, Melda. (2013). Simulasi Numeris Perubahan Garis Pantai Sasak Akibat Pembangunan Groin. Sumatra Barat: Univeristas Ekasakti Padang.

[3] Sutikno Sigit dkk (2015). Model Numerik Untuk Simulasi Alternatif Perlindungan Pantai Berbasis Sistem Informasi Geografis. Annual Civil Engineering Seminar 2015, Pekanbaru ISBN: 978-979-792-636-6.

[4] USACE. (1984). Shore Protection Manual. Coastal Engineering Research Center, Department Of The Army, U.S. Army Corps Of Engineers.

[5] Mulyabakti dkk (2016). Analisis Karakteristik Gelombang Dan Pasang Surut Pada Daerah Pantai Paal Kecamatan Likupang Timur Kabupaten Minahasa Utara. Jurnal Sipil Statik Vol.4 No.9 September 2016 (585-594) ISSN: 2337-6732.

[6] Hanson, H., and Kraus, N. C. (1991). GENESIS: Generalized Model for Simulating Shoreline Change. Report 1. 